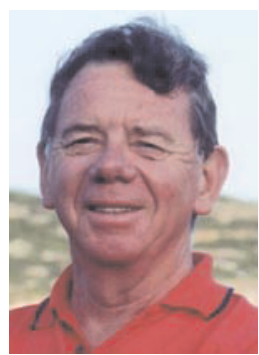

\title{
John Ewart Cawte AO, MB BS, MD, DPM, PhD, FRANZCP, FRCPsych, FAPA
}

JOHN CAWTE had an extraordinary passion for the human condition that made him an innovator in the field of transcultural psychiatry. His mentors included anthropologist Margaret Mead and Kamilaroi Elder Bill Reid. His belief that doctors working with Indigenous people had to understand and respect the different cultural and spiritual belief systems of their patients - a given today - was revolutionary for its time.

Born in Adelaide in 1925, John graduated from the University of Adelaide Medical School in 1949.

From 1951 to 1963, he was Superintendent at Enfield Receiving House in Adelaide - an experience eloquently described in his memoir The last of the lunatics (Melbourne University Press, 1998). From 1955 to 1956, John studied community-based psychiatry as a Harkness Fellow at Johns Hopkins and Harvard Universities.

In the early 1960s, John helped to establish the University of New South Wales School of Psychiatry and School of Public Health and Community Medicine. He held a personal chair in psychiatry and community medicine at the university until his retirement in 1991.

Spending all his free time working in remote communities, John recognised earlier than most the important role of traditional healers, documented in Medicine is the law: studies in psychiatric anthropology of Australian tribal societies (University Press of Hawaii, 1974).
In 1967, he developed the Arid Zone Project, establishing medical and community services centred around Bourke in western NSW. The project continued for 30 years and was a model for university-community partnerships. Through it, University of NSW academics, including Fred Hollows, formed warm relationships with Aboriginal leaders and developed holistic models of health and community services.

In 1977, John founded the Aboriginal Health Worker, now in its fourth decade of national publication. An initiated member of the Warramirri clan from Elcho Island, he worked with the Elders to help record some of their healing practices - at their request - to promote cultural understanding. This project resulted in the publication of The universe of the Warramirri: art, medicine and religion in Arnhem Land (UNSW Press, 1993) and Healers of Arnhem Land (UNSW Press, 1996).

In 1989, John was made an Officer of the Order of Australia, for his services to psychiatry and Aboriginal health.

John died, aged 86, at Little Bay on 26 October 2011, and is survived by his five children and five grandchildren.

Rose Ellis, Max Kamien

doi: $10.5694 /$ mjall.11534 